\title{
Continuous Rotation of Three Large Biomass Crops With High Bioconcentration Factor of Cadmium Can Effectively Repair Contaminated Farmlands
}

\section{Linhan Chen}

Hunan Agricultural University https://orcid.org/0000-0002-9563-5214

\section{Wenjun Yang}

Hunan Agricultural University

\section{Yang Yang}

Hunan Agricultural University

\section{Pengfei Tu}

Hunan Agricultural University

Shengnan $\mathrm{Hu}$

Hunan Agricultural University

Qingru Zeng ( $\nabla$ qrzeng@163.com )

Hunan Agricultural University

\section{Research Article}

Keywords: Cadmium, large biomass crops, multiple mowing system, crop rotation, economic value, plant bioconcentration

Posted Date: January 12th, 2022

DOI: https://doi.org/10.21203/rs.3.rs-1154155/v1

License: (9) This work is licensed under a Creative Commons Attribution 4.0 International License. Read Full License 


\section{Abstract}

Traditional phytoremediation is one means for remediation of heavy metal pollution. For developing countries, the key factor in promoting the practical application of phytoremediation in polluted soils is selecting suitable plants tolerant to heavy metals and using these to produce products with economic value. A chicory-tobacco-peanut, three-season, rotation field experiment was carried on the utilization and remediation of cadmium (Cd) in contaminated farmlands. The results showed that all three crops had a strong capacity to accumulate $\mathrm{Cd}$, with bioconcentration factors of chicory, tobacco, and peanut 6.61 to $11.97,3.85$ to 21.61 , and 1.36 to 7 , respectively. The yield of total dry biomass and phytoextraction efficiency for $\mathrm{Cd}$ reached $32.4 \mathrm{tha}^{-1}$ and $10.3 \%$ per year, respectively. The aboveground tissues of the three crops accounted for $83.9-91.2 \%$ of the total biomass in this rotation experiment. The content of peanut grain and oil met the National Food Safety Standard of China $\left(0.5 \mathrm{mg} \mathrm{kg}^{-1}\right.$, GB 2762-2017) and the Food Contaminant Limit of the European Union $\left(0.1 \mathrm{mg} \mathrm{kg}^{-1}, 18812006\right)$. Therefore, in addition to being used for phytoremediation in contaminated soils, this crop rotation system can also lead to economic benefits for local farmers.

\section{Introduction}

In the past 30 years, China's economy has experienced rapid development, which has led to increases in energy consumption and environmental pollution (Hu, Jin, and Kavan 2014). From 2000 to 2019, the cadmium (Cd) content in China's farmland soil increased twofold, and that in urban soil increased threefold, and nearly $33.5 \%$ and $44.7 \%$ of farmland and urban soils, respectively, were contaminated by Cd (Yuan, Xue, and Han 2021). Li et al. (2018) found that $86.0 \%$ of paddy fields were contaminated by Cd in eastern Hunan Province, China. Cd in the soil is absorbed by wheat, rice, and other food crops, thus harming humans that consumed these staple foods (Yang et al. 2022). Cd-contaminated soil now has become a worldwide environmental problem. (Walter et al. 2002; Ahmadi Doabi, Karami, and Afyuni 2019; Huang et al. 2007).

Phytoremediation (including phytoextraction, phytostabilization, rhizofiltration, and phytovolatilization) has been developed and refined in heavy metal soil treatments due to various advantages, such as little secondary pollution and reduced associated environmental damage (Yang, Zhou, et al. 2017).

Phytoextraction, the use of plants to directly remove pollutants from the environment can be used to clean contaminated soil at a low cost (Marques, Rangel, and Castro 2009). The selection of suitable plants to cultivate in Cd-contaminated soil is the focus for efficient overall extraction. Indexes such as accumulation capacity (Schickler and Caspi 1999), the bioaccumulation factor (BCF) (Luo et al. 2020), the translocation factor (TF) (Goswami and Das 2015), and tolerance capacity (Yang et al. 2004), are used to assess whether a specific plant has robust phytoextraction ability. Several studies have revealed the mechanism of interactions between plants and pollutants and provided important information for selecting plant species with significant metal accumulation potential (Lasat 2002; Liu et al. 2016). 
Research has shown that under high Cd stress, the content of Cd in hyper-accumulator plants, such as Solanum nigrum L. and Sedum alfredii, exceeded $100 \mathrm{mg} \mathrm{kg}^{-1}$, the BCF and TF were greater than 1, and the growth of plants was not inhibited (Wei 2005; Yang et al. 2004). Conversely, it can take decades for hyper-accumulators with poor environmental adaptability, low biomass, and slow growth to reduce $\mathrm{Cd}$ contents in the soil below environmental standards. In China, farmland contaminated by heavy metals is mostly at low to moderate levels and, importantly, farmers' main economic income depends on these farmlands (Yuan, Xue, and Han 2021). Because of the poor environmental adaptability and low biomass of most hyper-accumulating plants, the recovery efficiency of heavy metals remains limited. With this in mind, it is necessary to search for a new method for phytoremediation in Cd-contaminated farmlands.

Research by Glass (2000) suggested that phytoremediation of heavy metal-contaminated soils could be a significant business opportunity. Recently developed phytomanagement strategies, such as incorporating economic benefits into phytoremediation, will no longer view contaminated soil solely as a problem, but also as an economic opportunity (Evangelou and Deram 2014). As a result, the time it takes to treat soil becomes a less important restraint (Fässler et al. 2010). Ideally, plants used for plant management should grow rapidly and have high biomass to produce non-food economic products that partially compensate for operating costs (Evangelou et al. 2015). Increasing the concentration of heavy metals in plant tissues is reduced in importance relative to the feasibility of cultivation (Robinson et al. 2009). Much attention has focused on the potential for phytomanagement of trees, agricultural plants, and herbaceous crops, including willow (Salix L.), sorghum (Sorghum bicolor), and reed (Phragmites australis). Biomass from these crops can be processed into many products, including ethanol, biodiesel, or paper (Sharma et al. 2020; Marchiol et al. 2013; Marchiol et al. 2007).

Chicory (Cichorium intybus L.) is well-known for being used as food, medicine, (Menne, Guggenbuhl, and Roberfroid 2000), and animal feed (Ubeynarayana et al. 2021). In 1990, chicory with high drought tolerance, nutrient content, and environmental benefits was introduced to New Zealand, which helped to reduce nitrate leaching losses from grazed grassland systems because of its deeper root system (Ubeynarayana et al. 2021). Furthermore, it has been demonstrated as a species that can accumulate heavy metals from contaminated sites (Simon et al. 1995). However, the remediation potential of chicory in Cd-contaminated fields under different mowing treatment programs has rarely been investigated. Peanut (Arachis hypogaea L.) and tobacco (Nicotiana tabacum L.) are two important agricultural plants and both are good accumulators of Cd (King and Hajjar 1990; Damodharam 2008). Yet, few studies to date have considered the application of crops with both high economic value and heavy metal accumulation capacity for a yearly-rotation system using field trials.

We carried out a three-season rotation experiment to investigate: (i) bioconcentration capacity and remediation potential of chicory in Cd-contaminated soils; (ii) crop biomass, Cd accumulation capacity, and soil remediation efficiency under a three-season rotation system; (iii) soil Cd distribution before and after rotation restoration.

\section{Materials And Methods}


The field experiment was carried out in Zhuzhou, Hunan Province, China, which has a subtropical monsoon climate with an average annual temperature of $16-18^{\circ} \mathrm{C}$. Zhuzhou is a famous grain production area and an important national commodity grain base with a total area of 11,262 square kilometers; it had a population of 4,028,500 in 2019. As an old-line, heavy industrial zone in China, the long-term metal smelting has caused serious heavy metal pollution to the surrounding farmlands. This experiment was performed in a contaminated agricultural field $\left(27^{\circ} 69^{\prime} 5^{\prime \prime} \mathrm{N}, 113^{\circ} 56^{\prime} 13^{\prime \prime} \mathrm{E}\right)$ near the retired Zhuzhou Smelter area, which was the largest zinc-based alloy production facility in the world. Large areas of agricultural land have been contaminated by diffusion because of historic metal-smelting activities (Li et al. 2014).

The experimental field consisted of 3 plots (each $\left.25 \mathrm{~m}^{2}\right)$. Nine subsamples of topsoil ( $0-20 \mathrm{~cm}$ depth) were collected and blended into one soil sample at each plot, and each plot had three duplicate soil samples. The basic physicochemical characteristics and contents of copper ( $\mathrm{Cu})$, zinc ( $\mathrm{Zn}$ ), lead (Pb), and cadmium (Cd) were measured. The three crops (i.e., chicory, peanut, and tobacco) were grown on a one-year rotation on the three plots in the contaminated field. The rotation order was as follows. Chicory was sown in October 2019 at a density of 15 plants $\mathrm{m}^{-2}$. When the height of the aboveground plant reached $30 \mathrm{~cm}$, mowing was carried out and stubble was left at $5-7 \mathrm{~cm}$. The whole plants were harvested in April 2020 and the aboveground tissues from each mowing were collected. Tobacco (2 plants $\mathrm{m}^{-2}$ ) was then planted in each plot and the whole plants were harvested between Late April and Early August 2020; the leaves were harvested according to the upper, middle, and lower thirds. When tobacco was harvested, peanut (12 plants $\mathrm{m}^{-2}$ ) was planted and the whole plants were harvested between Mid-August and November 2020. Each plot was plowed and routinely fertilized before planting, watered regularly during the growing periods, and weeds were manually removed when necessary. No other additives or pesticides were used. Plants (20 plants of chicory and peanut and 10 plants of tobacco) at five locations in each plot were randomly sampled and combined for laboratory analyses; each part of the collected plants was weighed in the laboratory.

\section{Analytical methods}

Topsoil samples collected from each plot were dried at $60{ }^{\circ} \mathrm{C}$, crushed, and passed through 2 then 0.15 $\mathrm{mm}$ sieves. The $\mathrm{pH}$ value of each sample (soil: $\mathrm{H}_{2} \mathrm{O}, 1: 2.5$ ) was measured using a pH meter (PHS-3C), organic matter (OM) was determined by the Walkley-Black method, and cation exchange capacity (CEC) was determined using the ammonium acetate saturation method (Yang, Zhou, et al. 2017). The speciation of heavy metals in the soil was measured using the BCR sequential extraction procedure described previously (Zeng et al. 2018). Total soil $\mathrm{Cu}, \mathrm{Pb}, \mathrm{Zn}$, and $\mathrm{Cd}$ were measured after mixed acid $\left(\mathrm{HCl}-\mathrm{HNO}_{3}-\mathrm{HClO}_{4}\right)$ digestion (Page et al. 2014). The three crop samples (including roots, stems, leaves, seeds, and husks) were rinsed with tap water and then washed with deionized water. All the plant samples were oven-dried at $105^{\circ} \mathrm{C}$ for $2 \mathrm{~h}$ and then $60^{\circ} \mathrm{C}$ until completely dry (48 h), then ground into a powder with a grinder (WB200, Wei Bo Chuang, Beijing, China). Plant powders were digested in a mixture 
of $\mathrm{HNO}_{3}-\mathrm{HClO}_{4}(85: 15 \%, \mathrm{v} / \mathrm{v})$. Oil was extracted from peanut seeds according to a standard method using a Soxhlet apparatus with n-hexane as the solvent(Subramanian et al. 2016). Coupled plasma-optical emission spectrometry (Optima 8300, PerkinElmer, USA) or a graphite furnace flame atomic absorption spectrometer (Zhao, Mcgrath, and Crosland 1994) (SpectrAA-GTA120; Varian, USA) was used to determine the total heavy metal contents of soil, plants, and oils.

Data analysis

BCF (bioconcentration factor) was calculated using Eq. (1), as follows:

$\mathrm{BCF}=\frac{\mathrm{C}_{1}}{\mathrm{C}_{2}} \times 100 \%$

In this expression, $\mathrm{C}_{1}\left(\mathrm{mg} \mathrm{kg}^{-1}\right)$ is $\mathrm{Cd}$ concentration measured in the all parts of the plant, including root and the aboveground parts, while $\mathrm{C}_{2}\left(\mathrm{mg} \mathrm{kg}^{-1}\right)$ is total $\mathrm{Cd}$ concentration in the soil.

Metal uptake was calculated using Eq. (2) as follows:

Metal uptake $\left(\mathrm{g} \mathrm{ha}^{-1}\right)=\mathrm{C}_{\mathrm{Cd} \text { in plant }}\left(\mathrm{mg} \mathrm{kg}^{-1}\right) \times \mathrm{W}_{\text {biomass }}\left(\mathrm{kg} \mathrm{ha}^{-1}\right)$

$$
\times \mathrm{S}_{\text {cultivate area }} \text { (ha) }
$$

Theoretical phytoextraction efficiency (\%) was calculated using Eq. (3) (Yang, Ge, et al. 2017). It was assumed that heavy metal contamination was only in the rhizosphere soil zone $(0-20 \mathrm{~cm})$, which gave a soil bulk density of $1.3 \mathrm{t} \mathrm{m}^{-3}$.

Theoretical phytoextraction efficiency $(\%)=$

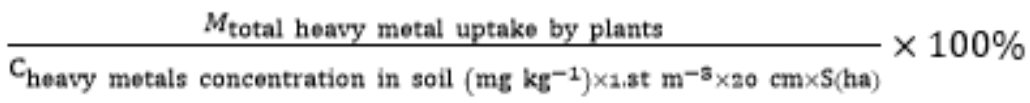

All the data were expressed as mean \pm standard deviation and were analyzed with Origin Pro 2018 and Excel 2019. One-way analysis of variance (ANOVA) and Duncan's multiple range test was performed using SPSS v23.0. All samples were analyzed based on biological triplicates.

\section{Results}

\section{Soil characteristics}

Descriptive statistics of soil characteristics and heavy metal concentrations in topsoil $(0-20 \mathrm{~cm})$ are presented in Table 1. The tested soil was classified as an ordinary gleyic-hydragric anthrosol based on the FAO World Reference Base for Soil Resources, with pH of 5.4 , OM content of $41.36 \mathrm{~g} \mathrm{~kg}^{-1}$, CEC of 
$10.05 \mathrm{cmol} \mathrm{kg}^{-1}$, total $\mathrm{N}$ content of $1.89 \mathrm{~g} \mathrm{~kg}^{-1}$, total $\mathrm{P}$ content of $0.59 \mathrm{~g} \mathrm{~kg}^{-1}$, and total $\mathrm{K}$ content of 1.25 $\mathrm{g} \mathrm{kg}^{-1}$. The soil total $\mathrm{Cu}, \mathrm{Zn}, \mathrm{Pb}$, and $\mathrm{Cd}$ contents were $25.96,87.88,2.66$, and $0.33 \mathrm{mg} \mathrm{kg}^{-1}$, respectively. The deposition of exhaust gas from smelters is usually the cause of heavy metal contamination in topsoil (John, Vanlaerhoven, and Bjerring 1976). According to the risk control standard for soil contamination of agricultural land of China ( $\mathrm{pH} \leq 6.5$, GB15618-2018), this area had low levels of Cd in the soil.

Table 1

Basic biochemical properties of the test soil

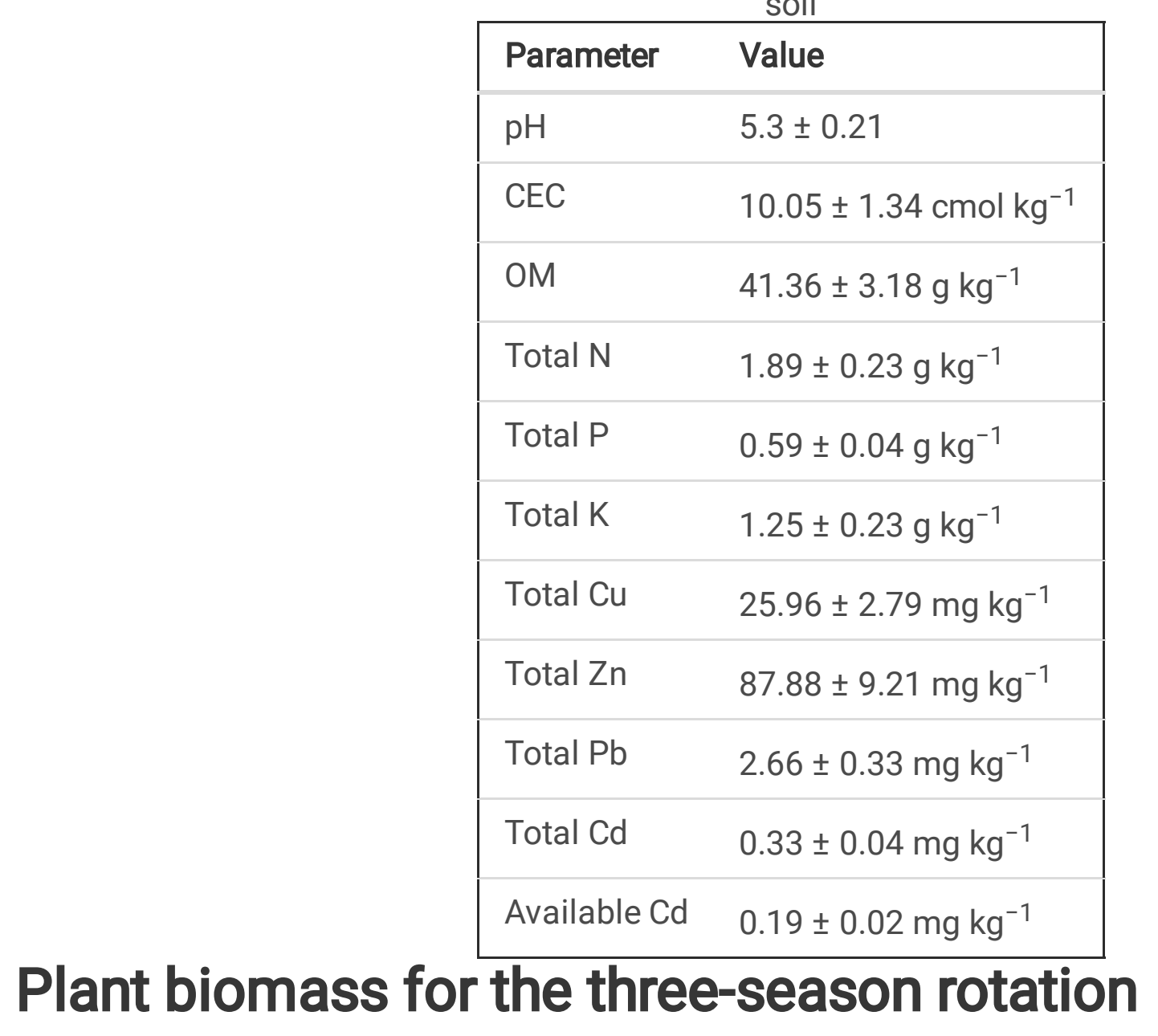

After a one-year rotation in the Cd-contaminated agricultural soil, none of the crops showed symptoms of deficiency, and yields remained within usual ranges for the region. The biomass (dry weight) of the three crops under the rotation system is shown in Fig. 1. There are significant differences in the different tissues of the three crops. Chicory was usually removed only at harvest time, so the total biomass of chicory was the leaves at each cutting and the roots at harvest. Chicory grown in winter or spring was mowed 7 times. The average biomass of chicory was $10.85 \mathrm{t} \mathrm{ha}^{-1}$, of which the root and leaf yields accounted for $8.8 \%$ and $91.2 \%$, respectively. It is worth noting that the aboveground biomass did not decrease significantly with the increase in the number of mowings. The biomass of chicory leaves in the last harvest was $72.5 \%$ of the first harvest. The average biomass of chicory was $10.62 \mathrm{t} \mathrm{ha}^{-1}$, of which the root, stem, and leaf yields accounted for $16.1 \%, 30.4 \%$, and $53.5 \%$, respectively. The biomass of 
tobacco leaves at different heights showed a trend of middle leaf $>$ lower leaf $>$ upper leaf. The biomass of different tissues in peanut was significantly different, among which the biomass of peanut stem (4.19 $\left.\mathrm{tha}^{-1}\right)$ was higher than that of other tissues, followed by that of grain $\left(2.42 \mathrm{tha}^{-1}\right)$. This would indicate that peanut could achieve considerable economic value while being used as a phytoremediation source.

The aboveground biomass of chicory, tobacco, and peanut was $9.89,8.91$, and $9.86 \mathrm{t} \mathrm{ha}^{-1}$, respectively. A total of $28.66 \mathrm{t} \mathrm{ha}^{-1}$ of usable biomass were harvested in the three-season rotation system.

\section{Cd adsorption, bioconcentration factors, and transfer factors of three-season rotation}

Figure 2 shows the $\mathrm{Cd}$ content, bioconcentration factors (BCF), and transfer factors (TF) of the threeseason rotation. Significant differences in Cd distribution were found between the three crops. The $\mathrm{Cd}$ content of chicory collected 7 times ranged from 2.24 to $3.11 \mathrm{mg} \mathrm{kg}^{-1}$, and the corresponding BCF of Cd ranged from 6.79 to 9.42 . The content of $\mathrm{Cd}$ in leaves of chicory decreased with the increase of cutting times, and the content of $\mathrm{Cd}$ in leaves of chicory ranged from 2.14 to $3.94 \mathrm{mg} \mathrm{kg}^{-1}$. The BCF of Cd in chicory leaves ranged from 6.48 to 11.97 , and TF ranged from 0.7 to 1.76. The content of $\mathrm{Cd}$ in leaves of chicory was higher than that in roots for the first three mows, but with the increase of cutting times, the content of Cd in leaves of chicory was lower than that in roots, which made the TF of chicory $<1$ in the last four harvests.

The content of $\mathrm{Cd}$ in tobacco leaves was significantly higher than that in roots and stems. The distribution of $\mathrm{Cd}$ content in tobacco leaves was spatially correlated, the Cd content showed a trend of lower leaf $>$ middle leaf $>$ upper leaf. The concentration of $\mathrm{Cd}$ in leaves ranged from 3.25 to $7.13 \mathrm{mg} \mathrm{kg}^{-1}$. Correspondingly, the BCF of $\mathrm{Cd}$ in tobacco leaves ranged from 10-12, and the TF of each tissue was greater than 1.

Peanut had the highest $\mathrm{Cd}$ content in roots and the lowest in grains. The $\mathrm{Cd}$ content showed a trend of root $>$ stem $>$ leaf $>$ husk $>$ seeds. The $C d$ content of each tissue of peanut ranged from $0.45-2.31 \mathrm{mg}$ $\mathrm{kg}^{-1}$ and the BCF of Cd ranged from 1.36-7.00. Correspondingly, the TF of peanut root to other tissues was $<1$. The Cd content of peanut seed was $0.45 \mathrm{mg} \mathrm{kg}^{-1}$, which is lower than the National Food Safety Standards of China ( $0.5 \mathrm{mg} \mathrm{kg}^{-1}$, GB 2762-2017). The Cd content of peanut oil extracted by n-hexane was only $0.017 \mathrm{mg} \mathrm{kg}^{-1}$, which is lower than the Food Contaminant Limit of the European Union ( $0.1 \mathrm{mg}$ $\left.\mathrm{kg}^{-1}, 18812006\right)$. Therefore, both peanut seeds and extracted peanut oil planted on Cd-contaminated soil could be used safely.

\section{Changes of soil Cd fraction in the three-season rotation}

Phytoremediation processes in the three crops altered the chemical fraction of the residual $\mathrm{Cd}$ in the soil (Fig. 3). Before the three-season rotation, the dominant chemical forms of $\mathrm{Cd}$ in the farmlands were the exchangeable (33.3\%), reducible (27.3\%), and oxidizable (24.2\%) fractions. Compared with the farmland without crops (CK), Cd in the exchangeable fraction was most efficiently extracted by the three-season 
rotation, as shown by a significant reduction of $4.0-7.7 \%$. By contrast, the proportion of $\mathrm{Cd}$ in the oxidizable and residual fractions increased by $1.6 \%$ and $6.0 \%$, respectively. This was because the phytoextraction of the rotation system removed a certain amount of $\mathrm{Cd}$.

\section{Cd uptake and theoretical phytoextraction efficiency}

The total uptake amount and remediation efficiency of soil $\mathrm{Cd}$ are shown in Table 2. The chicory biomass harvested after each mowing had a high accumulation of $\mathrm{Cd}$, which rendered the total $\mathrm{Cd}$ extraction $\left(32.21 \mathrm{~g} \mathrm{ha}^{-1}\right)$ and phytoextraction efficiency $(3.87 \%)$ of chicory robust. Tobacco had the highest $\mathrm{Cd}$ extraction in the rotation system, with a total accumulation of $37.47 \mathrm{~g} \mathrm{ha}^{-1}$. Although the extraction of $\mathrm{Cd}$ was only 2.05 and $4.75 \mathrm{~g} \mathrm{ha}^{-1}$ in roots and stems of tobacco, the lower and middle leaves of tobacco had a strong capacity to accumulate the metal- a total of $30.7 \mathrm{~g} \mathrm{ha}^{-1}$ of $\mathrm{Cd}$ was extracted from tobacco leaves. Therefore, tobacco was also a good phytoremediation material with a $\mathrm{Cd}$ accumulation of $94.5 \%$ aboveground. Compared with chicory and tobacco, peanut had a weaker $\mathrm{Cd}$ accumulation capacity, with a $\mathrm{Cd}$ accumulation of $16.03 \mathrm{~g} \mathrm{ha}^{-1}$. Stems and leaves were the main tissues of peanut $\mathrm{Cd}$ accumulation, and the proportion of $\mathrm{Cd}$ accumulation was $53.6 \%$ and $19.7 \%$, respectively. The $\mathrm{Cd}$ accumulation of the three crops showed a trend of tobacco > chicory > peanut. Through one year's rotation, a total of $85.71 \mathrm{~g}$ $\mathrm{ha}^{-1}$ of $\mathrm{Cd}$ could be removed from the three crops, and thus the theoretical total phytoextraction efficiency reached $10.3 \%$ year $^{-1}$.

Table 2

Cd uptake $\left(\mathrm{g} \mathrm{ha}^{-1}\right)$ and phytoextraction efficiency (\%) in the three-season rotation system.

\begin{tabular}{|llllll|}
\hline Chicory & $\begin{array}{l}\text { Cd uptake } \\
\left(\mathbf{g ~ h a}^{-1}\right)\end{array}$ & Tobacco & $\begin{array}{l}\text { Cd uptake } \\
\left(\mathbf{g ~ h a}^{-1}\right)\end{array}$ & Peanut & $\begin{array}{l}\text { Cd uptake } \\
\left(\mathbf{g ~ h a}^{-1}\right)\end{array}$ \\
\hline Leaf 1st & $6.57 \pm 0.77 \mathrm{a}$ & Root & $2.05 \pm 0.31 \mathrm{~d}$ & Root & $2.45 \pm 0.43 \mathrm{c}$ \\
\hline Leaf 2nd & $5.36 \pm 0.96 \mathrm{ab}$ & Stem & $4.75 \pm 0.79 \mathrm{c}$ & Stem & $8.59 \pm 0.35 \mathrm{a}$ \\
\hline Leaf 3rd & $5.05 \pm 0.62 \mathrm{~b}$ & Lower leaf & $14.52 \pm 1.86 \mathrm{a}$ & Leaf & $3.16 \pm 0.59 \mathrm{~b}$ \\
\hline Leaf 4th & $3.63 \pm 0.27 \mathrm{c}$ & Middle leaf & $11.20 \pm 1.81 \mathrm{~b}$ & Husks & $0.73 \pm 0.05 \mathrm{e}$ \\
\hline Leaf 5th & $2.88 \pm 0.13 \mathrm{ef}$ & Upper leaf & $4.98 \pm 0.92 \mathrm{c}$ & Grain & $1.10 \pm 0.26 \mathrm{~d}$ \\
\hline Leaf 6th & $3.09 \pm 0.67 \mathrm{~d}$ & & & & \\
\hline Leaf 7th & $2.63 \pm 0.49 \mathrm{ef}$ & & & & \\
\hline Root 7th & $2.99 \pm 0.54 \mathrm{e}$ & & & & $16.03 \pm 1.44$ \\
\hline Total & $32.21 \pm 3.27$ & & $37.47 \pm 3.77$ & & $1.93 \%$ \\
\hline Removal efficiency & $3.87 \%$ & & & & \\
\hline
\end{tabular}


The total and available $\mathrm{Cd}$ contents in the soil before and after the three-season crop rotation also were determined. (Table 3). After phytoremediation, the soil total and available Cd contents decreased by $12.1 \%$ and $10.5 \%$, respectively, which were higher than the theoretical remediation efficiency. The soil total Cd content was lower than the soil environmental quality standard of China (GB15618-2018). In sum, this large-scale biomass crop rotation system can effectively remediate Cd-contaminated soil.

Table 3

Soil Cd content before and after phytoremediation $\left(\mathrm{mg} \mathrm{kg}^{-1}\right)$.

\begin{tabular}{|lllll|}
\hline & $\begin{array}{l}\text { CK } \\
\text { before }\end{array}$ & $\begin{array}{l}\text { CK } \\
\text { after }\end{array}$ & $\begin{array}{l}\text { Before } \\
\text { phytoremediation }\end{array}$ & $\begin{array}{l}\text { After } \\
\text { phytoremediation }\end{array}$ \\
\hline Total Cd & $0.33 \pm 0.01 \mathrm{a}$ & $0.34 \pm 0.02 \mathrm{a}$ & $0.33 \pm 0.01 \mathrm{a}$ & $0.29 \pm 0.01 \mathrm{~b}$ \\
\hline Removal efficiency of total Cd & & $-3.03 \%$ & & $12.12 \%$ \\
\hline Available Cd & $0.19 \pm 0.02 \mathrm{a}$ & $0.19 \pm 0.01 \mathrm{a}$ & $0.19 \pm 0.02 \mathrm{a}$ & $0.17 \pm 0.02 \mathrm{a}$ \\
\hline $\begin{array}{l}\text { Removal efficiency of } \\
\text { available Cd }\end{array}$ & & $0 \%$ & & $10.53 \%$ \\
\hline
\end{tabular}

\section{Discussion}

In the focal study sites, BCF values of the aboveground portion of chicory reached 6.61-11.97 (Fig. 2), which indicates that chicory has a strong $\mathrm{Cd}$ accumulation capability. The higher the $\mathrm{Cd}$ concentration in the aboveground tissues indicates efficient translocation of $\mathrm{Cd}$ from roots to the shoots, which is a recognized feature of hyperaccumulating plants (Tang et al. 2017). Abe et al. (2008) compared the ability of shoots and roots of 93 weeds to accumulate $\mathrm{Cd}$ in sandy soils and found that Cd concentration was the highest in the shoots of chicory. The ability of chicory to accumulate $\mathrm{Cd}$ may be related to the upregulation of $\mathrm{Cd}$ transporter expression. A previous study showed that the expression levels of ZIP and Nramp family proteins related to $\mathrm{Cd}$ transport in Cd hyper-accumulators are significantly higher than those of ordinary plants (Cappa and Pilon-Smits 2014). In addition, heavy metals are distributed in the leaves of super-enriched plants. The detoxification mechanism of Argentina chicory is probably through the effective distribution of $\mathrm{Cd}$ in vacuoles, and the vacuoles become a reservoir for $\mathrm{Cd}$ transportation to the ground (Lasat 1996; Yao et al. 2017).

When chicory was mowed repeatedly, it maintained high Cd accumulation capacity and biomass (Fig. 1, 2), which is not possible for many other Cd hyper-accumulators. Increasing plant production is an effective way to increase plant enrichment capacity. Compared with other phytoremediation efficiency promotion methods, mowing is a low-cost agricultural measure that can improve phytoremediation efficiency without secondary pollution. Cd accumulation of Napier grass increased by $107.9-110.5 \%$ after one mowing (Yang et al. 2020). Yang et al. (2017) proposed a way to increase the accumulation of $\mathrm{Cd}$ in tobacco by mowing twice. However, the results of the Yang et al. (2020) study also showed that the second mowing reduced the $\mathrm{Cd}$ concentrations in tobacco stems and leaves. This was true of chicory in 
our study, with increased mowing leading to decreased $\mathrm{Cd}$ content in the aboveground tissues. With an increasing trend in the belowground tissues, the biomass of the aboveground chicory tissues changed little, which is consistent with a previous study that the content of $\mathrm{Cd}$ among chicory was only related to plant variety and not plant size (Crush, Ouyang, and Cousins 2018). Furthermore, chicory grew well in weakly acidic soil and was not affected by multiple mowings (Fig. 1), which was consistent with the results reported by Crush and Evans Crush and Evans (1990) that the growth of shoots was not influenced by variations in soil pH from 4 to 6 .

Our research indicated, compared with other tissues, $\mathrm{Cd}$ mainly accumulates in tobacco leaves, which is consistent with a previous study, comparing multiple tobacco varieties, the accumulation of $\mathrm{Cd}$ in tobacco leaves is higher than that in roots and stems (Wagner and Yeargan 1986). It is also evident that the metal concentration in tobacco varies along the stem, and is higher in older than younger top leaves (Semu and Singh 1995). An earlier study showed that levels of Cd accumulate highest in the oldest tobacco leaves (Wagner and Yeargan 1986). In other words, Cd accumulation increases with the leaf age and is consistent with the time-dependent deposition of $\mathrm{Cd}$ in leaves. In our experiment, the content of $\mathrm{Cd}$ in lower leaves of tobacco was 1.37 and 2.13 times that in middle and upper leaves, respectively, which also supports time-dependent deposition. We also noticed the phenomenon that $\mathrm{Cd}$ accumulation in the lower leaves accounted for $38.8 \%$ of the total plant volume, while that in the middle and upper leaves accounted for only $29.9 \%$ and $13.3 \%$, respectively. Many factors, such as soil characteristics, agronomic practices, and environmental conditions, affect Cd uptake by tobacco (Lugon-Moulin et al. 2004). LugonMoulin et al. (2006) analyzed 755 tobacco leaf samples of 3 major types from 13 countries and found that biologically-available $\mathrm{Cd}$ and other soil characteristics contributed significantly to tobacco $\mathrm{Cd}$ content, indeed, the adsorption of $\mathrm{Cd}$ by clay irons, organic matter, and manganese oxides decrease in concert with pH (Alloway 1990). Tobacco leaves showed higher average BCF values of Cd (Fig. 2) which could be due to its high availability in the low pH soils.

Peanuts also accumulated a portion of $\mathrm{Cd}$ in the three-season rotation system (Table 2). Gao et al. (2012) found that the vegetative growth of peanut plants was depressed under high $\mathrm{Cd}$ conditions, but stimulated under low $\mathrm{Cd}$ conditions. The distribution of $\mathrm{Cd}$ in various tissues of peanut was selective. Angelova et al. (2011) found that the distribution order of heavy metals in peanut was roots $\square$ \tems $\square$ leaves $\square$ fruit shell > seeds, which is consistent with our results. The accumulation of Cd was high in all the other parts of peanut and the BCF value of $\mathrm{Cd}$ was greater than 1 , except for the seeds. In addition, the ability to transport $\mathrm{Cd}$ from belowground to aboveground was far greater than that of root to husk and grain. Thus, the reasons for the accumulation of $\mathrm{Cd}$ in peanut are complex. In our experiment, inorganic fertilizer was also used, but the concentration of $\mathrm{Cd}$ in peanut grains was still very low, which may be related to the physical and chemical properties of the local soil.

China will need to import more than 15 million tons of edible oil by 2030 to meet domestic consumption demand (Tian et al. 2018). Therefore, it is of great significance to explore the safe production of peanut seeds and oil in the vast areas of Cd-contaminated farmland. Growing peanuts in Cd-contaminated farmland has proven to be a viable method for the production of plant-derived oil (Su et al. 2012). In our 
study, the Cd content of peanut grains did not exceed the limit of the National Food Safety Standard of China (0.5 mg kg-1, GB 2762-2017), and the Cd content of peanut oil was lower than the EU Food Contaminant Limit of EU $\left(0.1 \mathrm{mg} \mathrm{kg}^{-1}, 18812006\right)$. suggesting that farmers could make money while remediating Cd contaminations in the soil. Su et al. (2012) found that peanut grain oil was low (0.04$0.08 \mathrm{mg} \mathrm{kg}^{-1}$ ) when peanut was planted in 0,2 , and $4 \mathrm{mg} \mathrm{kg}^{-1} \mathrm{Cd}$-contaminated soil. A previous study also showed low $\mathrm{Cd}$ accumulation in peanut grains, which increased their protein content but did not affect oil content (Shi et al. 2014). Therefore, it is feasible to obtain safe peanut grains and peanut oil in Cd-contaminated soil. Moreover, peanut shell also is a good adsorption material, which can be used for the removal of Cd from polluted environmental areas (Cheng et al. 2016).

The chemical fraction of $\mathrm{Cd}$ in soil has important effects on potential environmental risks and phytoextraction efficiency (Wang et al. 2018; Gusiatin, Kulikowska, and Klik 2017). Previous work has demonstrated $\mathrm{Cd}$ in oxidizable and residual fractions are commonly at steady-state and induce relatively minor adverse effects in the environment (Yang et al. 2018). Conversely, the other fractions could induce large environmental risks because of their high bioavailability and bioactivity (Wu et al. 2015). The threeseason rotation system could effectively remove much of the active fraction of $\mathrm{Cd}$ from soils, which in turn reduces the bioavailability and environmental risk of $\mathrm{Cd}$, especially after the harvesting of chicory and tobacco.

Research on follow-up treatments of crop stalks has centered on biochar and compost and few studies have examined straw treatment after phytoremediation. Zhou et al. (2020) noticed that pyrolysis can effectively remove pollution residues in oil crop stalks, and the extract of the biochar can be used as fertilizer. Yang et al. (2017) showed that tobacco can also increase total biomass during phytoremediation with multiple mowings, removing $98.4 \% \mathrm{Cd}$ from leaves (using 0.5 hydrochloric acid) and had little influence on the concentration of key nutrients (i.e., $\mathrm{Ca}, \mathrm{Mg}, \mathrm{P}$, and K). Phytoremediation often faces two problems in farmlands. First, most of the materials used for heavy metal remediation are hyper-accumulators, which are often not accepted by Chinese farmers because the farmland in China is generally only mildly to moderately polluted by heavy metals and hyper-accumulators usually have no economic value (Thewys et al. 2010). Second, hyper-accumulators usually require an environment conducive to high growth rates. While they extract the targeted heavy metals from contaminated soil, they also remove other elements, including those needed for plant growth, such as $\mathrm{Zn}$ and $\mathrm{Cu}$ (Deng et al. 2007; Xv et al. 2020; Zu et al. 2004), which may affect the growth of subsequent crops. In our experiment, a conventional forage crop (chicory), a commercial crop (tobacco), and a conventional oil crop (peanut) were used as materials for crop rotation patterns, all three crops are familiar to farmers. Thus, this crop rotation system can not only effectively mediate Cd-contaminated farmland but also can be promoted widely as a viable economic alternative.

\section{Conclusions}

The chicory-tobacco-peanut rotation system can not only produce high plant biomass but also peanut grains and oils following the National Food Safety Standard of China (GB 2762-2017) and Food 
Contaminant Limit of the European Union (18812006). Therefore, this system is more suitable because the economic returns are more acceptable to farmers. The theoretical remediation efficiency of this rotation was $10.3 \%$, while the actual remediation efficiency for total and available $\mathrm{Cd}$ was $12.1 \%$ and $10.5 \%$, respectively. After a three-season rotation, soil Cd bioavailability decreased, while the proportion of residues increased. Our results indicated that the chicory-tobacco-peanut rotation system could effectively restore $\mathrm{Cd}$-contaminated farmland while still providing a viable economic alternative to farmers.

\section{Declarations}

\section{Author's contribution}

Linhan Chen: Formal analysis, Investigation, Data curation, Writing original draft, Software, Validation. Wenjun Yang: Data curation, Investigation. Yang Yang: Supervision, Data curation, Software, Methodology. Pengfei Tu: Software, Validation, Supervision. Shengnan Hu: Data curation, Methodology. Qingru Zeng: Conceptualization, Methodology, Resources, Writing-review \& editing, Data curation, Project administration, Supervision, Funding acquisition.

\section{Funding}

This work was supported by grants from National Natural Science Foundation of China (U20A20108), (No. 42077142).

\section{Ethical approval}

Not applicable.

\section{Consent to participate}

Not applicable.

\section{Consent to publish}

All the authors listed agree to submit the manuscript to the journal.

\section{Competing interests}

The authors declare no competing interests.

\section{Availability of data and materials}

All data generated or used during the study are available from the corresponding author by request.

\section{References}


Abe, Takuya, Motohiro Fukami, and Masaru Ogasawara. 2008. "Cadmium accumulation in the shoots and roots of 93 weed species." Review of. Soil Science and Plant Nutrition 54 (4):566-73. doi: 10.1111/j.1747-0765.2008.00288.x.

Ahmadi Doabi, Shahab, Mahin Karami, and Majid Afyuni. 2019. "Heavy metal pollution assessment in agricultural soils of Kermanshah province, Iran." Review of. Environmental Earth Sciences 78 (3). doi: 10.1007/s12665-019-8093-7.

Alloway, B. J. 1990. "Heavy Metals in Soils." Review of.

Angelova, Violina, Radka Ivanova, and K. Ivanov. 2011. "Heavy Metal Accumulation and Distribution in Oil Crops." Review of. Communications in Soil Science and Plant Analysis 35 (17-18):2551-66. doi: $10.1081 /$ lcss-200030368.

Cappa, J. J., and E. A. H. Pilon-Smits. 2014. "Evolutionary aspects of elemental hyperaccumulation." Review of. PLANTA 239 (2):267-75. doi: 10.1007/s00425-013-1983-0.

Cheng, Qiming, Qing Huang, Sardar Khan, Yingjie Liu, Zhenni Liao, Gang Li, and Yong Sik Ok. 2016. "Adsorption of $\mathrm{Cd}$ by peanut husks and peanut husk biochar from aqueous solutions." Review of. Ecological Engineering 87:240-5. doi: 10.1016/j.ecoleng.2015.11.045.

Crush, J., and J. P. M. Evans. 1990. "Shoot growth and herbage element concentrations of 'Grasslands Puna' chicory (Cichorium intybus L.) under varying soil pH." Review of. Proceedings of the New Zealand Grassland Association 51:163-6. doi: 10.33584/jnzg.1990.51.1893.

Crush, J. R., L. Ouyang, and G. R. Cousins. 2018. "Variation in cadmium concentrations in shoots of chicory ( Cichorium intybus L.)." Review of. New Zealand Journal of Agricultural Research:1-9.

Damodharam, Ndnsu. 2008. "Phytotoxicity of cadmium on protein, proline and antioxidant enzyme activities in growing Arachis hypogaea L. seedlings." Review of. Journal of Environmental Sciences.

Deng, D. M., W. S. Shu, J Zhang, H. L. Zou, and M. H. \%J Environmental Pollution Wong. 2007. "Zinc and cadmium accumulation and tolerance in populations of Sedum alfredi." Review of. 147 (2).

Evangelou, Michael, and Annabelle Deram. 2014. "Phytomanagement: A realistic approach to soil remediating phytotechnologies with new challenges for plant science." Review of. International Journal of Plant Biology \& Research 2:1023.

Evangelou, Michael W. H., Eleni G. Papazoglou, Brett Harvey Robinson, and Rainer Schulin. 2015. "Phytomanagement: Phytoremediation and the Production of Biomass for Economic Revenue on Contaminated Land." In Phytoremediation, 115-32.

Fässler, Erika, Brett H. Robinson, Werner Stauffer, Satish K. Gupta, Andreas Papritz, and Rainer Schulin. 2010. "Phytomanagement of metal-contaminated agricultural land using sunflower, maize and tobacco." 
Review of. Agriculture, Ecosystems \& Environment 136 (1-2):49-58. doi: 10.1016/j.agee.2009.11.007.

Gao, Fang, Ying-Jie Lin, Jia-Lei Zhang, Chuan-Ting Yang, Feng Zhang, Xiao-Kang Yang, Hua-Jian Zhao, and Xiang-Dong Li. 2012. "Effects of Cadmium Stress on Physiological Characteristics, Pod Yield, and Kernel Quality in Peanut." Review of. Acta Agronomica Sinica 37 (12):2269-77. doi: 10.1016/s18752780(11)60058-8.

Glass, D. J. 2000. "Economic potential of phytoremediation ; in Phytoremediation of Toxic Metals." Review of. Using Plants to Clean Up the Environment.

Goswami, S., and S. Das. 2015. "A Study on Cadmium Phytoremediation Potential of Indian Mustard, Brassica juncea." Review of. Int J Phytoremediation 17 (1-6):583-8. doi: 10.1080/15226514.2014.935289.

Gusiatin, Zygmunt M., Dorota Kulikowska, and Barbara Klik. 2017. "Suitability of humic substances recovered from sewage sludge to remedy soils from a former As mining area - a novel approach." Review of. Journal of Hazardous Materials 338:160-6. doi: https://doi.org/10.1016/j.jhazmat.2017.05.019.

Hu, Hui, Qian Jin, and Philip Kavan. 2014. "A Study of Heavy Metal Pollution in China: Current Status, Pollution-Control Policies and Countermeasures." Review of. Sustainability 6 (9):5820-38. doi: 10.3390/su6095820.

Huang, S. S., Q. L. Liao, M. Hua, X. M. Wu, K. S. Bi, C. Y. Yan, B. Chen, and X. Y. Zhang. 2007. "Survey of heavy metal pollution and assessment of agricultural soil in Yangzhong district, Jiangsu Province, China." Review of. Chemosphere 67 (11):2148-55.

John, M. K., C. J. Vanlaerhoven, and J. H. Bjerring. 1976. "Effect of a smelter complex on the regional distribution of cadmium, lead and zinc in litters and soil horizons." Review of. Archives of Environmental Contamination \& Toxicology 4 (4):456-68.

King, L. D., and L. M. Hajjar. 1990. "The Residual Effect of Sewage Sludge on Heavy Metal Content of Tobacco and Peanut." Review of. Journal of Environmental Quality 19 (4).

Lasat, M. M. 1996. "Physiological Characterization of Root Zn2+ Absorption and Translocation to Shoots in Zn Hyperaccumulator and Nonaccumulator Species of Thlaspi." Review of. Plant Physiol 112 (4):171522.

Lasat, Mitch M. 2002. "Phytoextraction of Toxic Metals." Review of. Journal of Environmental Quality 31 (1):109-20. doi: https://doi.org/10.2134/jeq2002.1090.

Li, Xuezhen, Zhongqiu Zhao, Ye Yuan, Xiang Wang, and Xueyan Li. 2018. "Heavy metal accumulation and its spatial distribution in agricultural soils: evidence from Hunan province, China." Review of. RSC Advances 8 (19):10665-72. doi: 10.1039/c7ra12435j. 
Li, Z., Z. Ma, T. J. van der Kuijp, Z. Yuan, and L. Huang. 2014. "A review of soil heavy metal pollution from mines in China: pollution and health risk assessment." Review of. Sci Total Environ 468-469:843-53. doi: 10.1016/j.scitotenv.2013.08.090.

Liu, K., F. Yu, M. Chen, Z. Zhou, C. Chen, M. S. Li, and J. Zhu. 2016. "A newly found manganese hyperaccumulator-Polygonum lapathifolium Linn." Review of. International Journal of Phytoremediation $18(4): 348-53$.

Lugon-Moulin, N., F. Martin, M. R. Krauss, P. B. Ramey, and L. Rossi. 2006. "Cadmium concentration in tobacco (Nicotiana tabacum L.) from different countries and its relationship with other elements." Review of. Chemosphere 63 (7):1074-86. doi: 10.1016/j.chemosphere.2005.09.005.

Lugon-Moulin, N., M. Zhang, F. Gadani, L. Rossi, and G. J. \%J Advances in Agronomy Wagner. 2004. "Critical Review of the Scienceand Options for Reducing Cadmium in Tobacco (Nicotiana Tabacum L. ) and Other Plants." Review of. 83:111-80.

Luo, Jie, Wenxiang He, Shihua Qi, Jian Wu, and Xiaowen Sophie Gu. 2020. "A novel phytoremediation method assisted by magnetized water to decontaminate soil Cd based on harvesting senescent and dead leaves of Festuca arundinacea." Review of. Journal of Hazardous Materials 383. doi: 10.1016/j.jhazmat.2019.121115.

Marchiol, L., G. Fellet, D. Perosa, and G. Zerbi. 2007. "Removal of trace metals by Sorghum bicolor and Helianthus annuus in a site polluted by industrial wastes: A field experience." Review of. Plant Physiology and Biochemistry 45 (5):379-87. doi: https://doi.org/10.1016/j.plaphy.2007.03.018.

Marchiol, Luca, Guido Fellet, Francesco Boscutti, Carlo Montella, Riccardo Mozzi, and Carmine Guarino. 2013. "Gentle remediation at the former "Pertusola Sud" zinc smelter: Evaluation of native species for phytoremediation purposes." Review of. Ecological Engineering 53:343-53. doi:

10.1016/j.ecoleng.2012.12.072.

Marques, Ana P. G. C., António O. S. S. Rangel, and Paula M. L. Castro. 2009. "Remediation of Heavy Metal Contaminated Soils: Phytoremediation as a Potentially Promising Clean-Up Technology." Review of. Critical Reviews in Environmental Science and Technology 39 (8):622-54. doi:

10.1080/10643380701798272.

Menne, E., N. Guggenbuhl, and M. Roberfroid. 2000. "Fn-type chicory inulin hydrolysate has a prebiotic effect in humans." Review of. Journal of Nutrition 130 (5):1197-9.

Page, K., M. J. Harbottle, P. J. Cleall, and T. R. Hutchings. 2014. "Heavy metal leaching and environmental risk from the use of compost-like output as an energy crop growth substrate." Review of. Sci Total Environ 487:260-71. doi: 10.1016/j.scitotenv.2014.04.021. 
Robinson, Brett H., Gary Bañuelos, Héctor M. Conesa, Michael W. H. Evangelou, and Rainer Schulin. 2009. "The Phytomanagement of Trace Elements in Soil." Review of. Critical Reviews in Plant Sciences 28 (4):240-66. doi: 10.1080/07352680903035424.

Schickler, Hedva, and Hadar Caspi. 1999. "Response of antioxidative enzymes to nickel and cadmium stress in hyperaccumulator plants of the genus Alyssum." Review of. Physiologia Plantarum 105 (1):3944. doi: https://doi.org/10.1034/j.1399-3054.1999.105107.x.

Semu, E., and B. R. Singh. 1995. "Accumulation of heavy metals in soils and plants after long-term use of fertilizers and fungicides in Tanzania." Review of. Fertilizer Research 44 (3):241-8.

Sharma, N., G. Barion, I. Shrestha, L. B. Ebinezer, A. R. Trentin, T. Vamerali, G. Mezzalira, A. Masi, and R. Ghisi. 2020. "Accumulation and effects of perfluoroalkyl substances in three hydroponically grown Salix L. species." Review of. Ecotoxicol Environ Saf 191:110150. doi: 10.1016/j.ecoenv.2019.110150.

Shi, G., G. Su, Z. Lu, C. Liu, and X. Wang. 2014. "Relationship between biomass, seed components and seed $\mathrm{Cd}$ concentration in various peanut (Arachis hypogaea L.) cultivars grown on Cd-contaminated soils." Review of. Ecotoxicol Environ Saf 110:174-81. doi: 10.1016/j.ecoenv.2014.09.003.

Simon, L., B. Kovacs, J. Prokisch, and Z. Gyori. 1995. "Bioindication of the heavy metal contamination of soils with chicory [Cichorium intybus L.]." Review of. Innocenti Occasional Papers Economic Policy 90 (17):7912-4.

Su, Genqiang, Fen Li, Jingshuang Lin, Caifeng Liu, and Gangrong Shi. 2012. "Peanut as a potential crop for bioenergy production via Cd-phytoextraction: A life-cycle pot experiment." Review of. Plant and SoiL 365 (1-2):337-45. doi: 10.1007/s11104-012-1394-1.

Subramanian, R., P. Subbramaniyan, J. Noorul Ameen, and V. Raj. 2016. "Double bypasses soxhlet apparatus for extraction of piperine from Piper nigrum." Review of. Arabian Journal of Chemistry 9:S537s40.

Tang, L., W. Luo, W. Chen, Z. He, H. K. Gurajala, Y. Hamid, M. Deng, and X. Yang. 2017. "Field crops (Ipomoea aquatica Forsk. and Brassica chinensis L.) for phytoremediation of cadmium and nitrate cocontaminated soils via rotation with Sedum alfredii Hance." Review of. Environ Sci Pollut Res Int 24 (23):19293-305. doi: 10.1007/s11356-017-9146-7.

Thewys, T., N. Witters, S. Van Slycken, A. Ruttens, E. Meers, F. M. Tack, and J. Vangronsveld. 2010. "Economic viability of phytoremediation of a cadmium contaminated agricultural area using energy maize. Part I: effect on the farmer's income." Review of. Int J Phytoremediation 12 (7):650-62. doi: 10.1080/15226514.2010.493187.

Tian, Z., Y. H. Ji, L. X. Sun, X. L. Xu, D. L. Fan, H. L. Zhong, Z. R. Liang, and G. Ficsher. 2018. "Changes in production potentials of rapeseed in the Yangtze River Basin of China under climate change: A multi- 
model ensemble approach." Review of. Journal Of Geographical Sciences 28 (11):1700-14. doi: 10.1007/s11442-018-1538-1.

Ubeynarayana, N., P. Jeyakumar, P. Bishop, R. C. Pereira, and C. W. N. Anderson. 2021. "Effect of soil cadmium on root organic acid secretion by forage crops." Review of. Environ Pollut 268 (Pt A):115839. doi: 10.1016/j.envpol.2020.115839.

Wagner, G. J., and R. Yeargan. 1986. "Variation in cadmium accumulation potential and tissue distribution of cadmium in tobacco." Review of. Plant Physiology (1):1.

Walter, Ingrid, Fernando Martínez, Luis Alonso, and José de Gracia Gabriela Cuevas. 2002. "Extractable soil heavy metals following the cessation of biosolids application to agricultural soil." Review of. Environmental Pollution 117 (2):315-21. doi: https://doi.org/10.1016/S0269-7491(01)00181-6.

Wang, G., S. Zhang, Q. Zhong, X. Xu, T. Li, Y. Jia, Y. Zhang, Wjgm Peijnenburg, and M. G. Vijver. 2018. "Effect of soil washing with biodegradable chelators on the toxicity of residual metals and soil biological properties." Review of. Science of the Total Environment 625 (JUN.1):1021-9.

Wei, Shuhe. 2005. "A newly-discovered Cd-hyperaccumulator Solanum nigrum L." Review of. Chinese Science Bulletin 50 (1). doi: 10.1360/982004-292.

Wu, Qing, Yanrui Cui, Qilu Li, and Jianhui Sun. 2015. "Effective removal of heavy metals from industrial sludge with the aid of a biodegradable chelating ligand GLDA." Review of. Journal of Hazardous Materials 283:748-54. doi: https://doi.org/10.1016/j.jhazmat.2014.10.027.

Xv, L., J. Ge, S. Tian, H. Wang, and L. \%J Environmental Pollution Lu. 2020. "A Cd/Zn Cohyperaccumulator and $\mathrm{Pb}$ accumulator, Sedum alfredii, is of high Cu tolerance." Review of. 263 (Pt B):114401.

Yang, W. J., J. F. Gu, H. Zhou, F. Huang, T. Y. Yuan, J. Y. Zhang, S. L. Wang, Z. G. Sun, H. W. Yi, and B. H. Liao. 2020. "Effect of three Napier grass varieties on phytoextraction of Cd- and Zn-contaminated cultivated soil under mowing and their safe utilization." Review of. Environ Sci Pollut Res Int 27 (14):16134-44. doi: 10.1007/s11356-020-07887-1.

Yang, Wenjun, Shilong Wang, Hang Zhou, Min Zeng, Jingyi Zhang, Fang Huang, Shiping Shan, et al. 2022. "Combined amendment reduces soil $\mathrm{Cd}$ availability and rice $\mathrm{Cd}$ accumulation in three consecutive rice planting seasons." Review of. Journal of Environmental Sciences 111:141-52. doi: 10.1016/j.jes.2021.03.027.

Yang, X. E., X. X. Long, H. B. Ye, Z. L. He, D. V. Calvert, and P. J. Stoffella. 2004. "Cadmium tolerance and hyperaccumulation in a new Zn-hyperaccumulating plant species (Sedum alfredii Hance)." Review of. Plant and Soil 259 (1):181-9. doi: 10.1023/B:PLSO.0000020956.24027.f2. 
Yang, Y., Y. Ge, H. Zeng, X. Zhou, L. Peng, and Q. Zeng. 2017. "Phytoextraction of cadmium-contaminated soil and potential of regenerated tobacco biomass for recovery of cadmium." Review of. Sci Rep 7 (1):7210. doi: 10.1038/s41598-017-05834-8.

Yang, Yang, Xihong Zhou, Boqing Tie, Liang Peng, Hongliang Li, Kelin Wang, and Qingru Zeng. 2017. "Comparison of three types of oil crop rotation systems for effective use and remediation of heavy metal contaminated agricultural soil." Review of. Chemosphere 188:148-56.

doi: https://doi.org/10.1016/j.chemosphere.2017.08.140.

Yang, Zong-Han, Cheng-Di Dong, Chiu-Wen Chen, Yih-Terng Sheu, and Chih-Ming Kao. 2018. "Using polyglutamic acid as soil-washing agent to remediate heavy metal-contaminated soils." Review of.

Environmental Science and Pollution Research 25 (6):5231-42. doi: 10.1007/s11356-017-9235-7.

Yao, S. Y., J. Liu, Y. X. Wang, Y. F. Zhu, and S. Feng. 2017. "Cd hyperaccumulation and accumulative kinetics of Celosia argentea Linn. for phytoremediation of Cd-contaminated soil." Review of. Journal of Agro-Environment Science.

Yuan, X., N. Xue, and Z. Han. 2021. "A meta-analysis of heavy metals pollution in farmland and urban soils in China over the past 20 years." Review of. J Environ Sci (China) 101:217-26. doi:

10.1016/j.jes.2020.08.013.

Zeng, Xinyi, Zhihua Xiao, Guolin Zhang, Andong Wang, Zihan Li, Yihan Liu, Hua Wang, Qingru Zeng, Yunshan Liang, and Dongsheng Zou. 2018. "Speciation and bioavailability of heavy metals in pyrolytic biochar of swine and goat manures." Review of. Journal of Analytical and Applied Pyrolysis 132:82-93. doi: https://doi.org/10.1016/j.jaap.2018.03.012.

Zhao, F., S. P. Mcgrath, and A. R. Crosland. 1994. "Comparison of three wet digestion methods for the determination of plant sulfur by inductively coupled plasma atomic emission spectroscopy (ICP-AES)." Review of. Communications in Soil Science \& Plant Analysis 25 (3):407-18.

Zhou, J., L. H. Chen, L. Peng, S. Luo, and Q. R. Zeng. 2020. "Phytoremediation of heavy metals under an oil crop rotation and treatment of biochar from contaminated biomass for safe use." Review of.

Chemosphere 247:125856. doi: 10.1016/j.chemosphere.2020.125856.

Zu, Y., L. Yuan, C. Schvartz, L. Langlade, and F. \%J Environment International Liu. 2004. "Accumulation of $\mathrm{Pb}, \mathrm{Cd}, \mathrm{Cu}$ and $\mathrm{Zn}$ in plants and hyperaccumulator choice in Lanping lead-zinc mine area, China." Review of. $30(4): 567-76$.

\section{Figures}



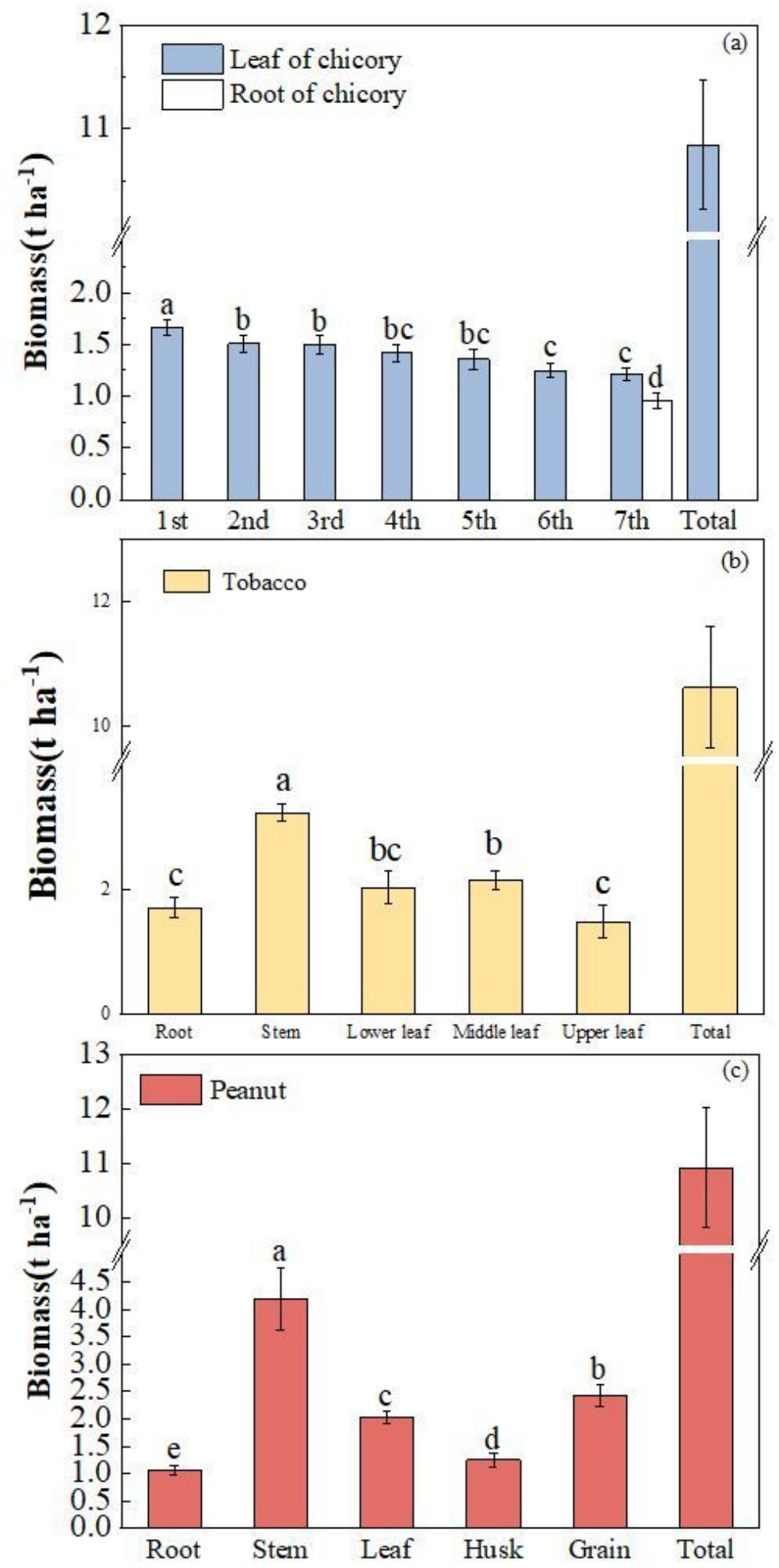

\section{Figure 1}

Biomass of chicory (a), tobacco (b), and peanut (c) in rotation pattern. Standard deviation is denoted as $\pm \operatorname{SD}(n=5)$. Different lowercase letters indicate statistically significant differences $(P<0.05)$. 

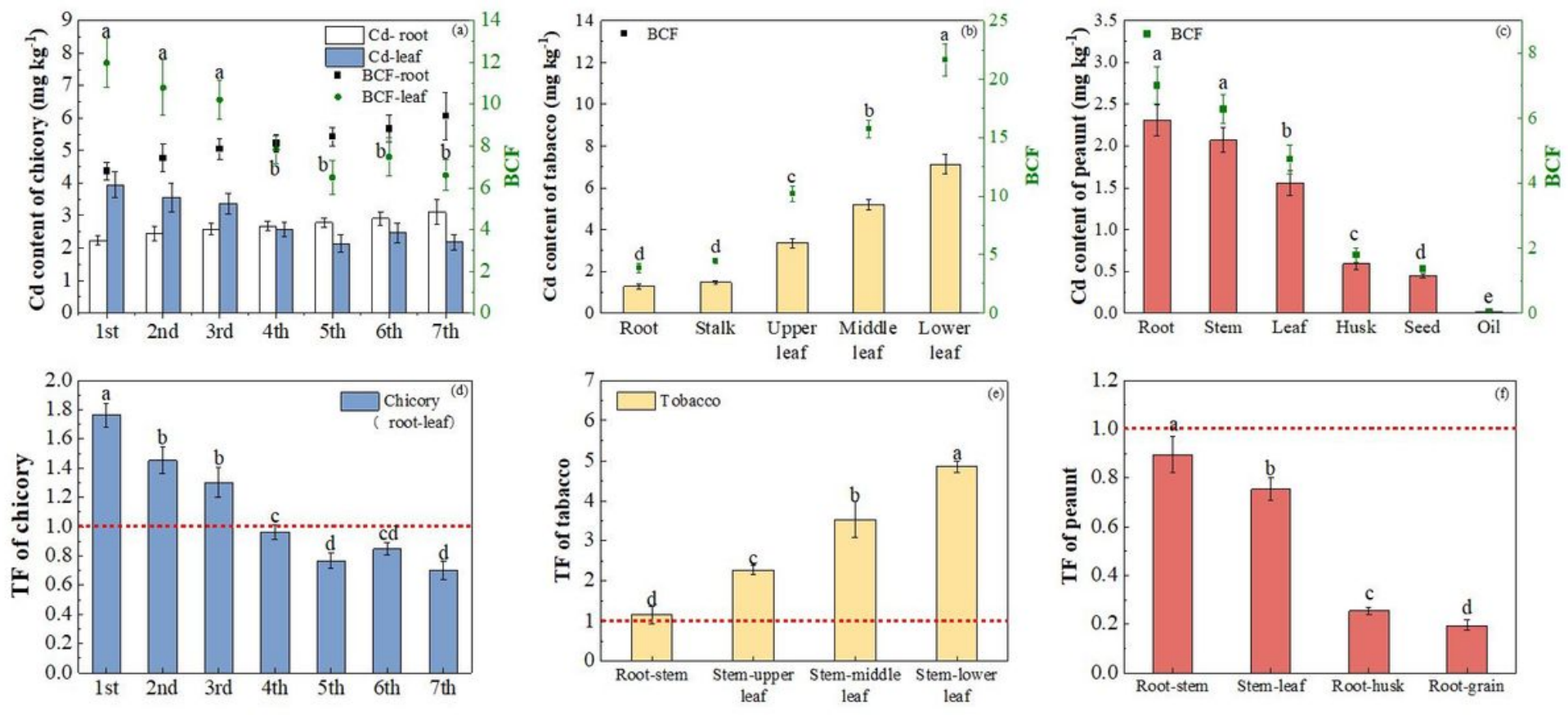

Figure 2

Cd content, bioconcentration factors, and transfer factors of the three-season rotation. Standard deviation is denoted as $\pm \operatorname{SD}(n=5)$. Different lowercase letters indicate statistically significant differences $(P<0.05)$. 


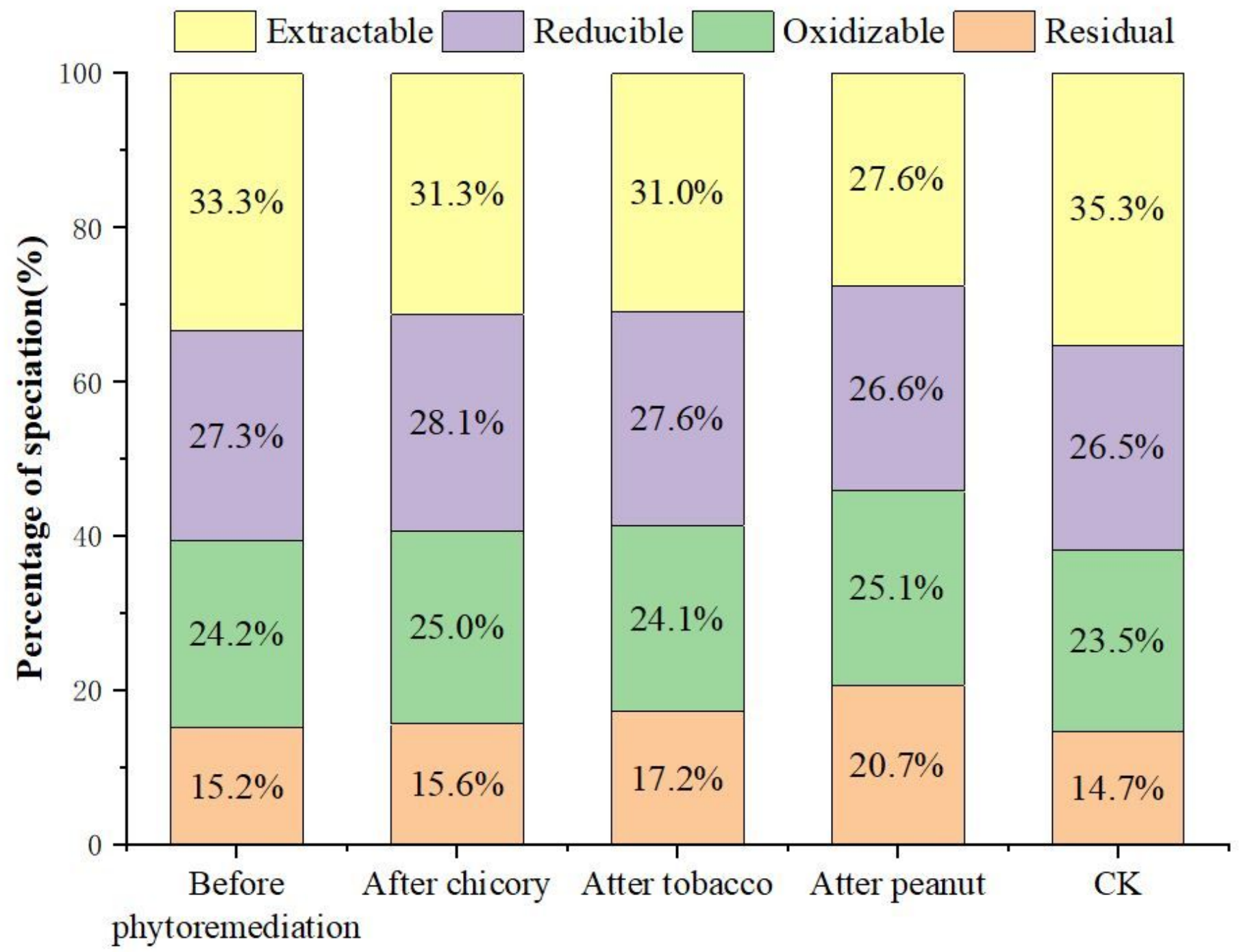

Figure 3

Speciation proportions of $\mathrm{Cd}$ in bulk soil during three-season rotation. 